Document downloaded from:

http://hdl.handle.net/10251/68536

This paper must be cited as:

Rosenthal, H.; Asturiano Nemesio, JF.; Horváth, A.; Martinez-Paramo, S. (2015). The Fourth International Workshop on the Biology of Fish Gametes, 17-20 September 2013, Albufeira, Algarve, Portugal: Summary and conclusions. Journal of Applied Ichthyology. 31(1):1-2. doi:10.1111/jai.12716.

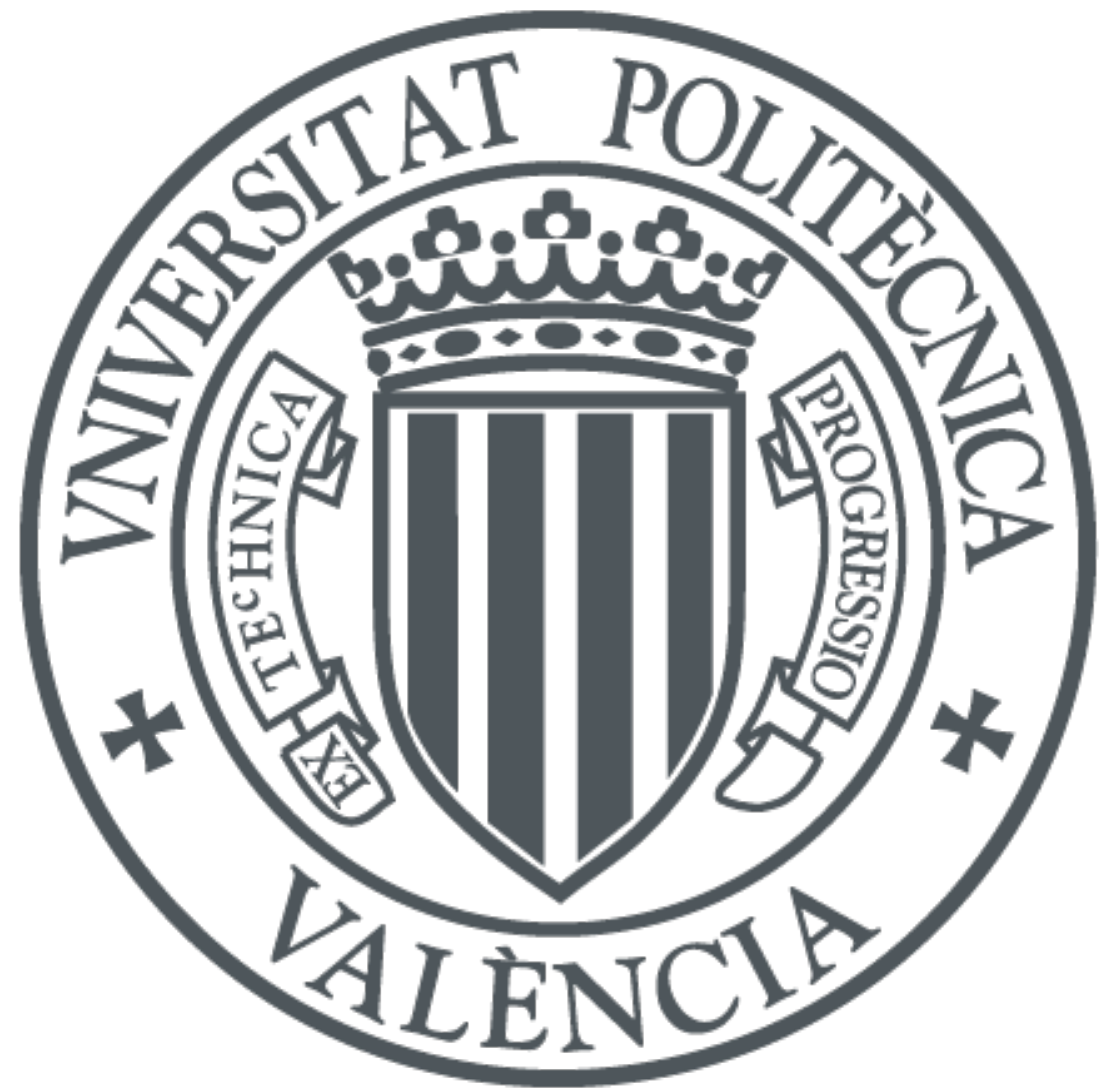

The final publication is available at

https://dx.doi.org/10.1111/jai.12716

Copyright Wiley

Additional Information 


\section{The Fourth International Workshop on the Biology of Fish Gametes, 17-20 September, 2013, Albufeira, Algarve, Portugal: Summary and conclusions}

This series of biennial international expert workshops started in 2007 in Vodnany, Czech Republic, when global experts on the biology of fish sperm gathered to share their experiencea and formulate recommendations on stressing scientific issues that need international cooperation to gain better basic knowledge and achieve technical breakthrough for a wider use of modern preservation methods in experimental biology and commercial application. The second workshop held in 2009 in Valencia, Spain, already formulated specific recommendations that expanded from spermatology to general fish gamete research and applications. During the third workshop in 2011 in Budapest, the scope of the agenda expanded further, focussing on three major topics: (a) Gamete preservation, (b) Gametogenesis, and (c) Gamete quality. Based on the gained experience and on the identified gaps in science and technology, the fourth Workshop held in 2013 in Albufeira, Portugal, focussed consequently on the following four topics: (a) Gametogenesis and gamete quality, (b) Gamete storage and preservation, (c) Gameto-“omics“" and emerging modern tools, and (d) Fertilization and progeny.

The interest in the subject has increased since the beginning. The fourth Workshop was attended by 118 participants from 24 countries. A total of 36 oral papers were presented and 71 posters were intensively discussed during the poster session. A special session dealt with the need for "standardization of experimental procedures". The need for standardization and for intercalibration of the evolving methodologies is an important issue that has been highlighted during the last forums, being one of the specific objectives of the AQUAGAMETE Cost Action (FA1205). In this special session, an effort was made to concretize this topic, addressing some specific points that should be standardized in reporting (e.g. definition of extender, final dilution of cryoprotectants in the extender).

Highlights of the sessions were:

a) Gametogenesis and gamete quality: novel information was presented on the differentiation processes of oocytes and spermatozoa as well as factors that influence gamete quality (e.g. temperature, probiotic diets, exposition to xenobiotics). Dr. Paz Herráez from the University of León (Spain) was the invited speaker of this session, who presented an interesting talk on this topic.

b) Gamete storage and preservation: the results presented in this session represented a compilation of the last advances on gametes and embryo cryopreservation and its applications including several aquatic species (fish and invertebrates), addressing different approaches to reduce cryodamage (e.g. reducing oxidative stress). Special thanks to Dr. Tiantian Zhang (Bournemouth University, UK) for her participation as invited speaker of this session with the talk "cryopreservation of fish gametes and its applications".

c) Gameto- "omics" and emerging tools: several studies were presented using the most modern techniques applied to characterize gamete quality including genomic, transcriptomic and proteomic analyses, DNA methylation, miRNAs, etc. A review on this topic was presented by Dr. Sebastiano Vilella (University of Salento, Italy), invited speaker of this session.

d) Fertilization and progeny: in this session it were shown interesting results on factors that directly affected fecundity, fertilization success and embryo development (e.g. hormonal induction, thermal regimes, parental microbial status) on several aquatic species. A special mention is required to Dr. Ferenc Müller (University of Birmingham, UK), invited speaker of this session, for his interesting talk "What does zebrafish tell us about how our genes get switched on?", focused on the maternal to zygotic transition during early embryonic development, and the existence of an epigenetic premarking mechanism acting before zygotic 
genome activation that may have implication in epigenetic inheritance from the gametes to the embryo.

This workshop also included two "How to do it?" practical sessions, in which the use of the free ImageJ CASA plug-in (Dr. Purchase, Memorial University of Newfoundland, Canada), and the techniques for primordial germ cell cryobanking (Dr. Cabrita, CCMAR/University of Algarve, Portugal) were demonstrated.

The COST Action FA1205 AQUAGAMETE played a vital role in the organization of this workshop by providing funding in the form of local organizer support as well as grants for earlystage researchers attending the meeting and giving oral presentations. The Action was planned during the previous workshop and was selected for funding by the COST office in 2012. Since its beginning it became a major driving force of the scientific community working with gametes of aquatic gametes. The Action's activities cover all aspects of aquatic gamete research therefore they provide an organic background for the works presented at the workshop.

The Fifth International Workshop on the Biology of Fish Gametes will be organized in September 2015 by Oliana Carnevali's team at the Department of Life and Environmental Sciences of Polytechnic University of Marche, Ancona, Italy.

We would like to thank the organizers (Sonia Martínez-Páramo, Catarina C. V. Oliveira, Maria Teresa Dinis, Claudia Aragão, Sofia Engrola), the many local helpers (Rita Colen, Nadège Richard, Elsa Cabrita, Filipe Figueiredo, Maria Filipa Castanheira) and the many referees to keep the quality of the publication (K. Arai, J. Beirão, I. Butts, B. Dzyuba, P. Herráez, R. Kowalski, C. Labbé, F. Lahnsteiner, C. C. Mylonas, D. S. Peñaranda, M. Psenicka, V. Robles, C. Rougeot, A.Viveiros), some of them also members of the scientific committee (J.F. Asturiano, E. Cabrita, O. Carnevali, A. Ciereszko, J. Cosson, M.T. Dinis, C. Fauvel, Á. Horváth, Z. Krasznai, O. Linhart, L. Pérez, H. Rosenthal, T. R. Tiersch).

Harald Rosenthal

Juan F. Asturiano

Ákos Horváth

Sonia Martínez-Páramo 